\title{
HUBUNGAN FREKUENSI SENAM AEROBIK DAN ASUPAN KOLESTEROL TERHADAP KADAR KOLESTEROL DARAH WANITA USIA SUBUR DI PUSAT KEBUGARAN SYARIAH AGUNG FITNES MAKAMHAJI
}

\author{
Annissa Mustika Ayu' ${ }^{1}$, Mutalazimah², Isnaini Herawati ${ }^{3}$ \\ ${ }^{1}$ UPT Puskesmas Samarinda Kota Jl. Bhayangkara No. 4, Samarinda, Kalimantan \\ Timur 75121. Email: ${ }^{1}$ mustikamanis40@ gmail.com \\ ${ }^{2}$ Program Studi Ilmu Gizi Fakultas Ilmu Kesehatan Universitas Muhammadiyah \\ Surakarta. Jl. A. Yani, Pabelan, Kartasura, Surakarta. \\ Email: ${ }^{2}$ mutalazimah@ums.ac.id \\ ${ }^{3}$ Program Studi Fisioterapi Fakultas Ilmu Kesehatan Universitas Muhammadiyah \\ Surakarta. J1. A. Yani, Pabelan, Kartasura, Surakarta. \\ Email: isnaini.herawati@ums.ac.id
}

\begin{abstract}
ABSTRAK
Aktivitas fisik dan asupan makan merupakan faktor yang berpengaruh terhadap kadar kolesterol darah. Tujuan penelitian ini adalah untuk mengetahui hubungan antara frekuensi senam aerobik dan asupan kolesterol terhadap kadar kolesterol darah wanita usia subur di Pusat Kebugaran Syariah Agung Fitnes Makamhaji. Jenis penelitian ini adalah kuantitatif dengan pendekatan cross-sectional. Jumlah responden sebanyak 37 orang diperoleh dengan teknik simple random sampling. Data frekuensi senam aerobik didapatkan melalui wawancara, data asupan kolesterol didapatkan melalui food recall 24 jam sebanyak 4 kali, dan data kadar kolesterol didapatkan dengan pemeriksaan darah di laboratorium. Analisis menggunakan uji statistik pearson product moment. Hasil penelitian menunjukkan bahwa sebagian besar frekuensi senam aerobik responden kurang (43,2\%). Sebagian besar responden memiliki asupan kolesterol yang kurang $(54,1 \%)$. Responden yang memiliki kadar kolesterol yang normal sebesar (62,2\%). Responden dengan frekuensi senam yang baik memiliki kadar kolesterol yang normal lebih tinggi (100\%) dibandingkan dengan frekuensi senam yang kurang hanya $(12,5 \%)$. Responden dengan asupan kolesterol yang cukup memiliki kadar kolesterol normal lebih tinggi yaitu $(69,2 \%)$ dibandingkan dengan asupan kolesterol yang lebih yaitu $(58,3 \%)$. Ada hubungan frekuensi senam aerobik dengan kadar kolesterol $(\mathrm{p}=0,00)$, tidak ada hubungan asupan kolesterol terhadap kadar kolesterol darah $(\mathrm{p}=0,86)$.
\end{abstract}

Kata kunci : Asupan, kolesterol, senam aerobik, wanita usia subur

\begin{abstract}
Physical activity and food intake are factors that affect blood cholesterol levels. The purpose of the study was to determine the relationship between the frequency of aerobic exercise and cholesterol intake to blood cholesterol levels of women of childbearing age at Pusat Kebugaran Syariah Agung Fitnes Makamhaji. The type of
\end{abstract}


research was quantitative with cross-sectional approach. The number of respondents was 37 people obtained by simple random sampling. Aerobic gymnastics frequency data was obtained through interview, cholesterol intake data was obtained through 24 hours food recall 4 times, and cholesterol levels were obtained by spectrophotometry. The statistical test used was Pearson product moment. The results showed that most of the respondents indicated the frequency of aerobic gymnastics in a less category (43.2\%). Most of the respondents displayed less cholesterol intake $(54.1 \%)$. Respondents with normal cholesterol levels were $69.2 \%$ gave enough cholesterol intake, while respondents with more cholesterol intake indicated normal cholesterol levels were $58.3 \%$. There was the relationship between the aerobic exercise frequency with cholesterol levels $(\mathrm{p}=0.00)$. There was no correlation between cholesterol intake and blood cholesterol levels ( $\mathrm{p}$ $=0.86$ ).

Keywords: Intake, cholesterol, aerobic gymnastic, women of childbearing age

\section{PENDAHULUAN}

Kolesterol merupakan zat yang dibutuhkan oleh tubuh dan memiliki fungsi membantu seluruh proses enzimatis dalam tubuh. Kadar kolesterol dalam darah dapat dipengaruhi oleh berbagai faktor diantaranya, keturunan, makanan, usia, jenis kelamin, aktivitas fisik, dan produksi kolesterol dari dalam tubuh. Hiperkolesterol merupakan suatu kondisi kadar kolesterol dalam darah sudah melebihi batas normal yaitu $200 \mathrm{mg} / \mathrm{dl}$ (Hartono, 2006). Kondisi hiperkolesterol yang terus menerus dan tidak terkontrol akan mengakibatkan beberapa macam penyakit. Menurut Riskesdas tahun 2013 sebanyak $69,6 \%$ penduduk Indonesia dalam kondisi hiperkolesterol, dan 39,6\% diantaranya berasal dari jenis kelamin perempuan. Sebagian besar penderita hiperkolesterol ditemukan didaerah perkotaan (Riskesdas, 2013).

Wanita usia subur masih aktif memproduksi hormon esterogen. Berbeda dengan wanita usia subur yang menggunakan kontrasepsi hormonal, alat kontrasepsi hormonal menyebabkan hormon estrogen tidak seimbang, yang berakibat pada penurunan HDL (High Density Lipoprotein) dan peningkatan LDL (Low Density Lipoprotein) hal tersebut akan mengakibatkan peningkatan kolesterol total (Dasuki et.al, 2008).

Olahraga dapat menurunkan kolesterol total dan kolesterol LDL (Low Density Lipoprotein) serta dapat meningkatkan kolesterol HDL (High Density Lipoprotein), menghilangkan lipatan lemak, dan membakar banyak kalori (Khomsan, 2003). Salah satu olahraga yang baik untuk kesehatan ialah olahraga aerobik yang berupa senam atau biasa disebut dengan senam aerobik (Giriwijoyo dan Zafar, 2013). Senam aerobik yang dilakukan 3 kali seminggu selama dua bulan sangat efektif untuk menurunkan berat badan, persen lemak tubuh, dan kadar kolesterol (Tri et al, 2012). Selain berolahraga, pola makan rendah kolesterol ikut berperan dalam menjaga kadar kolesterol tetap normal. Hasil penelitian menyatakan bahwa penduduk perkotaan memiliki pola konsumsi tinggi kolesterol (daging, telur, ayam) dibandingkan dengan penduduk pedesaan, oleh sebab itu penduduk perkotaan memiliki resiko hiperkolesterol 
lebih besar dibandingkan dengan penduduk pedesaan (Kahar, 2010). Peningkatan kadar kolesterol darah dapat dipicu dengan peningkatan asupan yang bahan makanannya mengandung kolesterol atau bahan makanan hewani (Khomsan, 2003). Penelitian menyatakan bahwa terdapat hubungan yang signifikan antara asupan kolesterol yang berlebih dengan kadar kolesterol darah (Septianggi et al, 2013).

Berdasarkan survei tetang kebiasaan makan yang dilakukan dengan menggunakan metode FFQ (Food Frequency) selama satu minggu dan pemeriksaan kadar kolesterol pada 16 anggota senam aerobik di Pusat Kebugaran Syariah Agung Fitnes, didapatkan $50 \%$ responden memiliki kebiasan mengkonsumsi makanan tinggi kolesterol, $65 \%$ responden memiliki frekuensi senam yang cukup (seminggu $\geq 3$ kali) dan $73 \%$ responden memiliki kadar kolesterol yang normal. Dari hasil survei di atas dapat disimpulkan bahwa responden yang mengkonsumsi makanan tinggi kolesterol dan melakukan senam aerobik dengan cukup akan memiliki kadar kolesterol yang normal.

Berdasarkan penjabaran di atas peneliti tertarik untuk mengetahui hubungan frekuensi senam aerobik dan asupan kolesterol terhadap kadar kolesterol darah Wanita Usia Subur (WUS) di Pusat Kebugaran Syariah Agung Fitnes.

\section{METODE PENELITIAN}

Penelitian ini menggunakan penelitian observasional dengan pendekatan cross sectional. Penelitian ini dilaksanakan pada bulan Maret hingga April 2016, lokasi penelitian dilaksanakan di Pusat Kebugaran Syariah Agung Fitnes Makamhaji. Teknik pengambilan sampel dalam penelitian ini menggunakan metode simple random sampling.

\section{Responden}

Kriteria inklusi dalam penelitian ini adalah wanita berusia 15-45 tahun dan melakukan jenis senam low impact durasi 60 menit/sesi. Sedangkan kriteria eksklusi yaitu sedang melakukan diet, merokok, minum alkohol, memiliki riwayat keluarga hiperkolesterol dan diabetes, mengkonsumsi atau menggunakan obat yang dapat mempengaruhi kadar kolesterol. Penelitian ini menggunakan data primer yang meliputi, identitas responden, frekuensi senam aerobik, asupan kolesterol dan kadar kolesterol total.

\section{Data frekuensi senam aerobik}

Data frekuensi senam aerobik diperoleh dengan wawancara langsung kepada responden. Frekuensi latihan 3-4 kali/minggu baik untuk menurunkan kadar kolesterol (AHA, 2016).

\section{Data asupan kolesterol}

Data asupan kolesterol didapatkan dengan metode food reccal 24 jam, untuk mendapatkan total asupan kolesterol diolah menggunakan aplikasi nutrisurvey. Anjuran untuk mengkonsumsi kolesterol ialah $\leq 300 \mathrm{mg} /$ hari (Linder, 2010).

\section{Data kadar kolesterol}

Data kadar kolesterol didapatkan dengan pemeriksaan kadar kolesterol darah dengan metode spektophotometri. Kadar kolesterol normal $<200 \mathrm{mg} / \mathrm{dl}$, sedangkan kadar kolesterol yang tinggi $\geq 200 \mathrm{mg} / \mathrm{dl}$ (Kemenkes, 2014).

\section{Analisis data}

Pengolahan dan analisis data menggunakan aplikasi SPSS 17. Mengetahui hubungan frekuensi senam aerobik dan asupan kolesterol dengan kadar kolesterol dianalisis menggunakan pearson product moment. 


\section{HASIL DAN PEMBAHASAN}

Pusat Kebugaran Syariah Agung Fitnes merupakan salah satu tempat kebugaran khusu wanita. Terletak di Jalan Kesatrian no 2 Makam Haji, Kartasura. Tempat kebugaran ini hanya buka pada saat sesi senam aerobik saja, yaitu hari senin, rabu, jum'at pukul $8.00,16.00$, dan 19.00 dan hari sabtu pukul 8.00. Pengambilan sampel dalam penelitian ini menggunakan simple random sampling, yang mana pengambilan sampel dilakukan secara acak. Pengambilan secara acak dilakukan pada setiap sesi senam dan didapatkan 39 responden dan 2 responden dinyatakan drop out dikarenakan menggunakan alat kontrasepsi hormonal dan tidak bisa dihubungi.

\section{Analisis Univariat}

Karakteristik responden dalam penelitian ini berdasarkan usia, jenis kelamin, pekerjaan, pendidikan terakhir, status pernikahan. Distribusi karekteristik responden ditampilkan pada Tabel 1 .

Tabel 1. Distribusi Karakteristik

\begin{tabular}{|c|c|c|}
\hline \multicolumn{3}{|c|}{ Responden } \\
\hline Variabel & Frekuensi & $\begin{array}{c}\text { Persentasi } \\
\%\end{array}$ \\
\hline \multicolumn{3}{|l|}{ Usia } \\
\hline $15-20$ th & 10 & 27 \\
\hline $21-25$ th & 7 & 18,9 \\
\hline $26-30$ th & 4 & 10,8 \\
\hline $31-35$ th & 5 & 13,5 \\
\hline$>35$ th & 11 & 29,7 \\
\hline \multicolumn{3}{|l|}{ Jenis Kelamin } \\
\hline Perempuan & 37 & 100 \\
\hline Laki-laki & - & - \\
\hline \multicolumn{3}{|l|}{ Pendidikan Terakhir } \\
\hline \multicolumn{3}{|l|}{ SMP } \\
\hline SMA & 6 & 16,2 \\
\hline \multirow[t]{2}{*}{ Perguruan Tinggi } & 22 & 59,5 \\
\hline & 9 & 24,3 \\
\hline \multicolumn{3}{|l|}{ Pekerjaan } \\
\hline Pelajar & 14 & 37,8 \\
\hline Ibu rumah tangga & 6 & 16,2 \\
\hline Swasta & 12 & 32,4 \\
\hline Guru & 2 & 5,4 \\
\hline Tenaga kesehatan & 3 & 8,1 \\
\hline \multicolumn{3}{|l|}{ Status Pernikahan } \\
\hline Menikah & 16 & 43,2 \\
\hline Belum Menikah & 21 & 56,8 \\
\hline
\end{tabular}

Wanita usia subur adalah wanita yang berusia 15-45 tahun (Riskesdas, 2013). Sampel dalam penelitian ini dikhususkan pada Wanita Usia Subur (WUS). Tabel 1 menggambarkan bahwa seluruh responden adalah Wanita Usia Subur.

Usia dan jenis kelamin merupakan faktor yang mempengaruhi kadar kolesterol. Wanita usia subur menghasilkan hormon esterogen yang dapat membantu menghasilkan kolesterol HDL (High Density Lipoprotein). Wanita usia subur cendrung memiliki kadar kolesterol lebih rendah dibandingkan dengan pria. Ketika wanita memasuki usia menopause kadar kolesterol cenderung mengalami peningkatan (AHA, 2016).

Tabel 1 menunjukkan 59,5\% responden memiliki pendidikan terakhir SMA. Seseorang yang memiliki tingkat pendidikan yang lebih tinggi akan mudah menyerap informasi dan mengiplementasikannya dalam prilaku dan gaya hidup sehari-hari khususnya dalam hal kesehatan dan gizi. Tingkat pendidikan ibu sangat mempengaruhi derajat kesehatan keluarga (Notoatmojo, 2007). Tabel 1 menunjukkan bahwa sebagian besar responden memiliki pekerjaan sebagai pelajar yaitu $37,8 \%$ dan sebagaian besar responden memiliki status pernikahan belum menikah yaitu 56,8\% .

Karakteristik responden dalam penelitian ini berdasarkan kondisi responden ditampilkan pada Tabel 2.

Tabel 2. Distribusi Frekuensi Kondisi Responden

\begin{tabular}{llcc}
\hline Variabel & Kategori & Frekuensi & $\begin{array}{c}\text { Persentase } \\
\text { \% }\end{array}$ \\
\hline Status & Baik & 26 & 70,3 \\
Gizi & Lebih & 11 & 29,7 \\
\hline Frekuensi & Baik & 12 & 32,4 \\
Senam & Kurang & 16 & 43,2 \\
& Lebih & 9 & 24,3 \\
\hline Asupan & Normal & 13 & 35,1 \\
Kolestreol & Kurang & 20 & 54,1 \\
& Lebih & 4 & 10,8 \\
\hline Kadar & Tinggi & 14 & 37,8 \\
Kolesterol & Normal & 23 & 62,2 \\
\hline
\end{tabular}


Ambang batas nilai normal untuk perempuan Indonesia adalah 18,5 - 25 . Statistik deskriptif status gizi berdasarkan nilai IMT (Indeks Masa Tubuh) dapat dilihat pada Tabel 3.

Tabel 3. Statistik Deskriptif Status Gizi

\begin{tabular}{lc}
\multicolumn{2}{c}{ Berdasarkan Nilai IMT } \\
\hline Statistik Deskriptif & Nilai IMT \\
\hline Mean & 24,31 \\
Standar Deviasi & 3,04 \\
Nilai Minimum & 19,73 \\
Nilai Maksimum & 32,66 \\
\hline
\end{tabular}

Responden dalam penelitian ini memiliki mean atau rata-rata nilai IMT (Indeks Masa Tubuh) sebesar 24,3 dengan nilai minimum 19,72 yang berarti tergolong dalam status gizi baik dan nilai maksimum 32,66 yang berarti tergolong dalam status gizi lebih. Walaupun ada beberapa responden yang memiliki status gizi lebih $(29,7 \%)$ akan tetapi dalam penelitian ini status gizi responden didominasi oleh status gizi baik 70,3\% .

Frekuensi senam adalah jumlah senam yang dilakukan selama 1 minggu (Wiarto, 2013). Penelitian ini melihat frekuensi senam selama 4 minggu. Frekuensi senam yang baik untuk menormalkan kadar kolesterol adalah dengan melakukan senam sebanyak 3-4 kali dalam seminggu (AHA, 2016). Karakteristik statistik deskriptif frekuensi senam selama 1 minggu dapat dilihat pada Tabel 4.

Tabel 4. Statistik Deskriptif Frekuensi Senam dalam Satu Minggu

\begin{tabular}{lc}
\hline Statistik Deskriptif & $\begin{array}{c}\text { Frekuensi Senam } \\
\text { seminggu }\end{array}$ \\
\hline Mean & 2,86 \\
Standar Deviasi & 1,572 \\
Nilai Minimum & 0,5 \\
Nilai Maksimum & 5,75 \\
\hline
\end{tabular}

Penelitian ini menggambil frekuensi senam selama 1 minggu selama 1 bulan, didapatkan mean atau rata-rata senam yang dilakukan oleh responden dalam satu minggu adalah 2,86 kali dengan nilai minimum 0,5 yang berarti frekuensi senam dalam satu minggu kurang, dan maksimum 5,75 yang berarti frekuensi senam dalam satu minggu lebih. Pada tabel 2 dapat dilihat bahwa responden yang memiliki frekuensi senam yang kurang lebih banyak (43,2\%) dibandingkan dengan responden yang memiliki frekuensi senam cukup $(32,4 \%)$ dan lebih (29,7\%). Aktifitas fisik yang berlebihan akan mengakibatkan cidera pada tubuh (Dewantari, 2011).

Asupan kolesterol dalam penelitian ini didapatkan dengan menggunakan metode food recall 24 jam. Hasil recall 24 jam kemudian diolah menggunakan aplikasi nutrisurvey guna mengetahui asupan kolesterolnya. Food Recall 24 jam dilakukan sebanyak 4 kali, setiap minggu responden dilakukan recall sebanyak 1 kali. Statistik deskriptif rata-rata asupan kolesterol per hari dapat dilihat pada Tabel 5.

Tabel 5. Statistik Deskriptif Rata-rata Asupan Kolesterol

\begin{tabular}{lc}
\hline Statistik Deskriptif & $\begin{array}{c}\text { Persentase } \\
\text { Asupan Kolesterol }\end{array}$ \\
\hline Mean & 82,3 \\
Standar Deviasi & 4,2 \\
Nilai Minimum & 32,91 \\
Nilai Maksimum & 131,15 \\
\hline
\end{tabular}

Didapatkan hasil asupan kolesterol memiliki mean atau rata-rata yaitu 243,65 $\mathrm{mg} / \mathrm{hari}$ dengan nilai minimum 98,74 $\mathrm{mg} /$ hari yang berarti asupan kolesterol sudah cukup dan nilai maksimum 393,45 $\mathrm{mg} /$ hari yang berarti asupan kolesterol berlebih. Tabel 2 menunjukkan bahwa konsumsi kolestreol berlebih oleh responden lebih mendominasi yaitu $64,9 \%$. Kolesterol merupakan bahan utama pembentukan garam empedu, asam folat, hormon adrenal, esterogen, androgen,dan progesteron selain itu kolesterol merupakan komponen utama sel otak dan saraf (Almatsier, 2004). Batas 
normal kadar kolesterol dalam darah adalah $<200 \mathrm{mg} / \mathrm{dl}$ (Wahyuningsih, 2013). Statistik deskriptif kadar kolesterol dapat dilihat pada Tabel 6 .

Tabel 6. Statistik Deskriptif Kadar Kolesterol

\begin{tabular}{lc}
\hline Statistik Deskriptif & $\begin{array}{c}\text { Kadar } \\
\text { Kolesterol }\end{array}$ \\
\hline Mean & 192,32 \\
Standar Deviasi & 33,92 \\
Nilai Minimum & 138,6 \\
Nilai Maksimum & 299,1 \\
\hline
\end{tabular}

Penentuan kadar kolesterol dalam penelitian ini menggunakan metode spektofotometry. Pemeriksaan kadar kolesterol dilaksanakan di minggu terakhir penelitian. Hasil pemeriksaan kadar kolesterol didapatkan mean atau rata-rata kadar kolesterol adalah 192,3 mg/dl dengan nilai minimum $138,6 \mathrm{mg} / \mathrm{dl}$ yang berarti kadar kolesterol normal dan nilai maksimum 299,1 mg/dl yang berarti kadar kolesterol tinggi. Terdapat beberapa responden yang memiliki kadar kolesterol yang tinggi akan tetapi responden yang memiliki kadar kolesterol normal mendominasi dalam penelitian ini $62,2 \%$.

\section{Analisis Bivariat Hubungan Frekuensi Senam Aerobik dengan Kadar Kolesterol}

Hubungan frekuensi senam aerobik dengan kadar kolesterol dapat dilihat pada Tabel 7.

Tabel 7. Hubungan Frekuensi Senam Aerobik dengan Kadar Kolesterol

\begin{tabular}{|c|c|c|c|c|c|c|c|}
\hline \multirow{3}{*}{$\begin{array}{c}\text { Frekuensi Senam } \\
\text { Aerobik }\end{array}$} & \multicolumn{4}{|c|}{ Kadar Kolesterol } & \multirow{2}{*}{\multicolumn{2}{|c|}{ Total }} & \multirow{3}{*}{ Nilai p } \\
\hline & \multicolumn{2}{|c|}{ Tinggi } & \multicolumn{2}{|c|}{ Normal } & & & \\
\hline & $\mathbf{N}$ & $\%$ & $\mathbf{N}$ & $\%$ & $\mathbf{N}$ & $\%$ & \\
\hline Cukup & 0 & 0 & 12 & 100 & 12 & 100 & \\
\hline Kurang & 14 & 87,5 & 2 & 12,5 & 16 & 100 & 0,00 \\
\hline Lebih & 0 & 0 & 9 & 100 & 9 & 100 & \\
\hline
\end{tabular}

Tabel 7 menunjukkan responden dengan frekuensi senam yang baik memiliki kadar kolesterol yang normal lebih tinggi (100\%) dibandingkan dengan frekuensi senam yang kurang hanya $(12,5 \%)$. Berdasarkan hasil uji data statistik menggunakan uji korelasi pearson product moment diproleh nilai $\mathrm{p}=0,00$. Hal ini menunjukkan bahwa $\mathrm{p}<0,05$ yang berarti ada hubungan frekuensi senam aeobik terhadap kadar kolesterol. Hal ini sejalan dengan hasil penelitian yang dilakukan oleh Tri dkk (2012) menyatakan senam aerobik yang dilakukan 3 kali seminggu selama dua bulan efektif menurunkan berat badan, persen lemak tubuh, dan kadar kolesterol.

Terdapat dua jenis senam aerobik, senam aerobik low impact dan high impact. Pada penelitian ini seluruh responden melakukan senam aerobik low impact. Gerakan low impact ialah kedua atau salah satu kaki selalu kontak dengan lantai, gerakan low impact cocok bagi pemula, dan irama dari senam ini bertahap dari ketukan yang lambat sampai ketukan yang agak cepat (Budiyono, 2015). Saat melakukan senam aerobik low impact, sistem kardiovaskuler dapat memenuhi kebutuhan oksigen pada saat latihan sehingga tubuh lebih dominan mengoksidasi lemak sebagai energi saat berkontraksi (Sudibjo et al., 2012). Aktivitas otot dapat membakar simpanan lemak dan trigliserida (Gyuton dan Hall, 2012) di jaringan adipose untuk menghasilkan energi (Sharkey, 2003), simpanan tersebut berasal dari pemecahan kolesterol dalam plasma (Roza, 2010), yang berakibat pada menurunkan kadar kolesterol (Gyuton dan Hall, 2012).

Selain dari pembakaran simpanan trigliserida dan lemak di otot, aktivitas olahraga yang teratur akan membantu 
menurunkan kadar kolesterol total dengan menaikkan kadar HDL (High Density Lipoprotein) dan menurunkan kadar LDL (Low Density Lipoprotein) (Sharkey, 2003). Olahraga yang teratur merangsang penurunan kadar hepatic TG lipase dan cholesterol ester transfer protein (CETP) yang berakibat pada peningkatan kadar HDL (High Density Lipoprotein), selain itu terjadi peningkatan enzim lipoprotein

lipase yang membantu LDL (Low Density Lipoprotein) di pembuluh darah bergerak menuju hati (Sugiarto et.al, 2015).

\section{Hubungan Asupan Kolesterol dengan Kadar Kolesterol}

Hubungan asupan kolesterol dengan kadar kolesterol dapat dilihat pada Tabel 8.

Tabel 8. Distribusi Asupan Kolesterol dengan Kadar Kolesterol

\begin{tabular}{|c|c|c|c|c|c|c|c|}
\hline \multirow{3}{*}{ Asupan Kolesterol } & \multicolumn{4}{|c|}{ Kadar Kolesterol } & \multirow{2}{*}{\multicolumn{2}{|c|}{ Total }} & \multirow{3}{*}{ Nilai $p$} \\
\hline & \multicolumn{2}{|c|}{ Tinggi } & \multicolumn{2}{|c|}{ Normal } & & & \\
\hline & $\mathbf{N}$ & $\%$ & $\mathbf{N}$ & $\%$ & $\mathbf{N}$ & $\%$ & \\
\hline Normal & 4 & 30,8 & 9 & 69,2 & 13 & 100 & \\
\hline Kurang & 7 & 35 & 13 & 65 & 20 & 100 & 0,317 \\
\hline Lebih & 3 & 75 & 1 & 25 & 4 & 100 & \\
\hline
\end{tabular}

Tabel 8 menunjukkan responden dengan asupan kolesterol yang normal memiliki kadar kolesterol normal lebih tinggi yaitu $69,2 \%$ dibandingkan dengan asupan kolesterol yang lebih $(25 \%)$ dan kurang $(65 \%)$. Berdasarkan hasil uji data statistik menggunakan uji korelasi pearson product moment diproleh nilai $\mathrm{p}=0,317$. Dapat disimpulkan bahwa tidak ada hubungan asupan kolesterol terhadap kadar kolesterol darah. Hasil penelitian ini tidak sejalan dengan penelitian yang dilakukan oleh Septianggi (2013) responden yang mengkonsumsi sumber kolesterol yang tinggi $(>200 \mathrm{mg} / \mathrm{hr})$ memiliki kadar kolesterol yang tinggi.

Di usus halus trigliserida dan kolesterol dari makanan dikemas menjadi partikel besar lipoprotein yang disebut kilomikron. Dalam aliran darah, kilomikron akan mengalami penguraian oleh enzim lipoprotein lipase sehingga akan membentuk asam lemak bebas dan kilomikron remnan. Asam lemak bebas menuju jaringan lemak dan otot, diubah menjadi trigliserida sebagai cadangan energi sedangkan kilomikron remnan akan di metabolisme dalam hati sehingga menghasilkan kolesterol bebas (Cakrawati dan Mustika, 2012).
Hati menghasilkan VLDL (Very Low Density Lipoprotein) dan HDL (High Density Lipoprotein) (Champe, 2011). VLDL dalam plasma di metabolisme oleh enzim lipoprotein lipase menjadi IDL (Intermediate Density Lipoprotein) kemudian IDL dengan serangkaian proses berubah menjadi LDL (Low Density Lipoprotein) yang kaya akan kolesterol (Sharkey, 2003). LDL (Low Density Lipoprotein) bertugas menghantarkan kolesterol dalam tubuh (Cakrawati dan Mustika, 2012). Pembuangan LDL (Low Density Lipoprotein) ke hati membutuhkan waktu sebanyak 2-5 hari (Sharkey, 2003).

Hasil penelitian ini tidak berhubungan bisa terjadi karena kolesterol yang bersumber dari luar bukan satusatunya faktor yang mempengaruhi kadar kolesterol. Asupan zat gizi lain ikut mempengaruhi kadar kolesterol darah. Salah satu zat gizi yang dapat mempengaruhi kadar kolesterol ialah serat. Serat berfungsi menghambat penyerapan kolesterol dari saluran pencernaan hal ini akan menurunkan ketersediaan kolesterol sehingga tranfer ke aliran darah berkurang, selain itu serat dapat mengikat dan meningkatkan sekresi 
asam empedu dan sterol melalui fese (Linder, 2010). Hasil penenlitian menunjukkan terdapat hubungan asupan serat terhadap kadar kolesterol, semakin rendah asupan serat akan berakibat pada peningkatan kadar kolesterol darah (Bintanah dan Handarsari, 2012).

\section{KESIMPULAN}

1. Sebagian besar responden memiliki frekuensi senam yang kurang $(\geq 3 \mathrm{kali}$ dalam 1 minggu) $43,2 \% \%$. Responden yang memiliki asupan kolesterol kurang, lebih banyak dibandingkan dengan asupan kolesterol yang tinggi dan normal $(54,1 \%)$. Sebanyak $62,2 \%$ responden memiliki kadar kolesterol yang normal.

2. Ada hubungan frekuensi senam aerobik dengan kadar kolesterol darah wanita usia subur di Pusat Kebugaran Syariah Agung Fitnes $(\mathrm{p}=0,00)$. Tidak ada hubungan asupan kolesterol dengan kadar kolesterol darah wanita usia subur di Pusat Kebugaran Syariah Agung Fitnes $(\mathrm{p}=$ 0,867).

\section{DAFTAR PUSTAKA}

Almatsier, S., 2004, Prinsip Dasar Ilmu Gizi (4th ed.), PT Gramedia Pustaka Utama, Jakarta, 63, 279.

Amerika Heart Association., 2016, American Heart Association Recommendations for Physical Activity in Adults. file:///C:/ Users/ PERSONAL/ Downloads/ American \% 20 Heart \% 20 Association \% 20 Recommendations \%20 for\% 20 Physical \% 20 Activity \% 20 in \% 20 Adults. Htm, diakses tanggal 3 Agustus 2016.

Badan Litbangkes., 2013, Riset Kesehatan Dasar (Riskesdas 2013), Depkes RI, Jakarta.

Bintanah, S,. Handarsari, E., 2012, Asupan Serat dengan Kadar Gula Dara. Kolesterol Total dan Status Gizi pada Pasien Diabetes Mellitus Tipe 2 di Rumah sakit Roemani Semarang. Hasil Penelitian. ISBN: 978-602-18809-0-6.

Budiyono, K., 2015, Amplikasi Senam Aerobic High Impact Dan Low Impact Terhadap Penurunan Presentase Lemak Tubuh Pada Kepala Sekolah Dasar SeKecamatan Banjarsari Surakarta, Jurnal Ilmiah Spirit. ISSN; 1411-8319. 15(1).

Cakrawati, D dan Mustika, NH., 2012, Bahan Pangan, Gizi dan Kesehatan, Alfabeta Bandung, 70-80.

Dasuki, D., Sanger, O., Sudrajat, JF. Pamuji, SE., 2008, Pengaruh Kontrasepsi Hormonal Planibu Versus Depo Progestin Terhadap Fungsi Hepar Dan Profil Lipid, Berita Kedokteran Masyarakat, 24(3). 156-161.

Dewantari, NM., Kayanaya, GR., Melantini., 2011, Perbedaan Perubahan Berat Badan Berdasarkan Frequensi Aerobik, Jurnal Ilmu Gizi. 2(1): 68-73. 
Giriwijoyo, S dan Zafar, D., 2013, Ilmu Faal Olahraga (Fisiologi Olahraga).PT Remaja Rosdakarya, Bandung, 8-11, 49.

Gyuton, CA., Hall, EJ., 2012, Buku Ajar Fisiologi Kedokteran (11th ed). Dialihbahasakan oleh: Irawati (et al.), EGC, Jakarta, 892, 889.

Hartono, A., 2006, Terapi Gizi dan Diet Rumah Sakit (2 $2^{\text {nd }}$ ed.), ECG, Jakarta, 28.

Kahar, M., 2010, Analisis Pola Konsumsi Daerah Perkotaan Dan Pedesaan Serta Keterkaitannya Dengan Karakteristik Sosial Ekonomi Di Propinsi Banten, Tesis, Institut Pertanian Bogor.

Kementrian Kesehatan RI., 2014, Pedoman Gizi Seimbang, Kementrian Kesehatan RI, Jakarta.

Khomsan, A., 2003, Pangan dan Gizi untuk Kesehatan, PT Raja Grafindo Persada, Jakarta, 55-58.

Linder, MC., 2010, Biokimia Nutrisi dan Metabolisme, Dialihbahasakan oleh: Parakkasi, A. UI Press, Jakarta, 77-78.

Notoatmodjo, S., 2007, Promosi Kesehatan dan Ilmu Prilaku, PT Rineka Cipta, Jakarta.

Roza, D., 2010, Pengaruh Aktifitas Fisik Terhadap Profil Lipid Wanita Usia Subur. Artikel Penelitian, 2(1):29-35.

Septianggi, FN., Mulyati, T., Sulistya, H., 2013, Hubungan Asupa Lemak dan Asupan Kolesterol Terhadap Kolesterol Total Pada Penderita Jantung Koroner Rawat Jalan di Rumah Sakit Tugurejo Semarang, 2(2). 13-20.

Sharkey, B., 2003, Kebugaran dan Kesehatan, Dialihbahasakan oleh: Nasution, DE. PT Raja Grafindo Persada, Jakarta, 14-16, 91-101, 309.

Sudibjo, P. Prakosa, J. Soebijanto., 2012, Pengaruh Senam Aerobik Intensitas Sedang Dan Intensitas Tinggi Terhadap Persentase Lemak Badan Dan Lean Body Weight, Fakultas Ilmu Keolahragaan Universitas Negeri Yogyakarta, 2-9.

Tri, UG., Junaidi, S., Rahayu, S., 2012, Latihan Senam Aerobik untuk Menurunkan Berat Badan, Lemak, dan Kolesterol, Jurnal Of Sport Sciences and Fitnes. 1(1): 6-10.

Wahyuningsih, R., 2013, Penatalaksanaan Diet pada Pasien, Graha Ilmu, Jogyakarta, 21,33 .

Wiarto, G., 2013, Fisiologi dan Olahraga, Graha Ilmu, Jogjakarta, 140. 